\title{
The Effectiveness of Programmable Logic Controller Teaching Aids for Control System Module in Vocational College
}

\author{
Muhammad Hazziq Bin Yahaya*, Mohamad Zaid Bin Mustafa, Rosnee Binti Ahad \\ Faculty of Technical and Vocational Education, University Tun Hussein Onn Malaysia (UTHM), Johor, Malaysia
}

Received August 23, 2019; Revised November 24, 2019; Accepted December 3, 2019

Copyright@2019 by authors, all rights reserved. Authors agree that this article remains permanently open access under the terms of the Creative Commons Attribution License 4.0 International License

\begin{abstract}
Teaching aids are important in the process of teaching and learning. The use of teaching aids in teaching and learning process is necessary for teachers to ensure the delivery of information related to the subjects taught is more visible and systematic, so it can be followed by students. This study aims to develop a programmable logic controller learning kit as a teaching aid to enhance the understanding of students in the control system module in a vocational college. This study implemented a quasi-experimental approach, involving two groups of fourth year students in vocational colleges that are enrolled in the control system module. A total of 60 respondents were randomly selected in cluster - 30 respondents from each vocational college. A pre-test and a post-test were conducted to assess the students' level of understanding on programmable logic controller topic. The pre-test and post-test have three parts which cover objective questions and subjective questions to ensure the similarity on the level of knowledge among respondents. The pre and post-test have the same question, but they were differentiated by the position of the question. A post-test will be given after the treatment and from the results, and the difference between the impact of the effective use of conventional method and the use of developed kit was analysed. Then, the questionnaires were distributed to 30 respondents to assess the effectiveness of the kit. The questionnaire covers three main aspects to be assessed. This learning kit can help teachers at vocational colleges to increase understanding and the knowledge of students on programmable logic controller topic in control system module. At the end of this study, the results have shown a positive effect on students' understanding of programmable logic controller topic. In addition, it can improve students' achievement in control system module in a vocational college.
\end{abstract}

Keywords Teaching Aids, Trainer Kit, Programmable Logic Controller

\section{Introduction}

Teaching aids are important in a learning process. The use of teaching aids can help to distribute information to students related to the subjects taught more clearly and systematically. Therefore, the use of teaching aids in the process of the learning could be a way to improve students' achievement in a classroom. Based on previous studies, the use of teaching aids in classroom has a positive impact in the learning process (Suparta, 2014; Mohd Nor \& Sharif, 2014; Prayoga, 2013; Ahmad \& Tamuri, 2010; Madar et al., 2009; Buntat \& Mohamad, 2010). In addition, the teaching aids can help to attract students' interest and attention and to deliver the content more effectively (Febriyanto, 2015; Kurniawan, Samani \& Soeryanto, 2013; Prayoga, 2013; Mohd Isa, 2012; Ahmad \& Tamuri, 2010; Madar et al., 2009). The use of teaching aids can also assist the students to understand the subject quickly (Alias, Ahmad \& Soowan, 2017; Abdullah, Zakaria \& Suaji, 2016; Abidin \& Jamaat, 2016; Prayoga, 2013; Mohd Isa, 2012). Teachers are able to explain things more accurately with assistance from teaching aids, compared to just by using word of mouth. In addition, the use of the teaching aids can lead to stimulation of various senses and with the proper and planned delivery, it will make a lesson more meaningful and effective (Mat Saat \& Abbas, 2016; Musa \& Muhammad, 2014; Ng, 2004). Teaching aids can be a way to ease teachers' burden when it comes to teaching because the tool can benefit the learning and also the teaching (Abidin \& Jamaat, 2016). These benefits that are being mentioned indicate the need for the researchers to produce this current study - to develop a learning kit.

Teaching aids possibly improve students' achievement in learning process. In a classroom, supporting materials such as teaching aids can guide teachers to provide a deeper 
understanding to students who have less knowledge in academics (Hastuti, Effendi \& Hijriani, 2017; Mat Saat \& Abbas, 2016; Ab Halim \& Lai, 2011; Ahmad \& Tamuri, 2010). However, at this moment, the use of teaching aids by the teacher in the classroom is still limited and low (Febriyanto, 2015; Suparta, 2014; Ambotang et. al, 2011; Ahmad \& Tamuri, 2010). There are also some teachers who do not use teaching aids while teaching (Abdullah, Zakaria \& Suaji, 2016; Nan \& Ziqiang, 2012; Jasmi et al., 2011). A study conducted by Salleh (2007) mentions that students are interested to learn through the use of teaching aids compared to using conventional method. According to Abdullah, Zakaria and Suaji, (2016), most teachers in vocational colleges do not include teaching aids for the learning process. The delivery in classroom only follows syllabus in the Standard Curriculum for Vocational College (KSKV) without the use of teaching aids to support the learning. This situation might be happening due to time constraint, lack of resource or expertise to develop it (Abdullah, Zakaria \& Suaji, 2016). In addition, many teachers simply use blackboard and only power point slides since the supplied teaching aids are not user friendly (Wan Harun et al., 2015). Consequently, teachers might have less confidence to carry out the teaching and learning in classroom because the learning process could be disrupted without the sufficient use of supporting materials. (Hamdan \& Ayop, 2010). Apart from that, learning objectives cannot be achieved due to less effective teaching and learning in the classroom.

Most subjects in vocational colleges require sophisticated teaching aids along with the circulation of times because the curriculum at vocational colleges requires students to use this facility. Vocational college students are exposed to various skills that enable them to improve their skills at an early stage to qualify them for Malaysia Vocational Diploma (KPM, 2013). To ensure that, this effort is realized in which teachers play an important role to shape the process of the learning in the classroom. In addition, teachers are also encouraged to ensure the learning process in the classroom is carried out more effectively. Therefore, to ensure this process runs smoothly, teachers should provide a facilitator or diversified teaching methods, so they can maximize the learning in classroom. For vocational college students, learning theory is insufficient and the learning needs to be infused with practical learning to make sure that students understand the learning better. Therefore, classroom learning requires the support of real media material (Hastuti, Effendi \& Hijriani, 2017; Mat Saat \& Abbas, 2016; Pathmantara, Wibawa \& Rahyu, 2015; Mohd Isa, 2012; Ahmad \& Tamuri, 2010).

Therefore, the idea of development of programmable logic controller learning kit as a teaching aid is expected to help teachers to diversify teaching methods in the classroom as well as to attract the interest of students in learning thereby providing an understanding and improving student achievement on the programmable logic controller topic.

\section{Literature Review}

\subsection{Constructivism Learning Theory}

Constructivism Learning Theory is one of the processes in which the experience is related to the existing knowledge of the students. This theory involves the suppression of student activities. According to Martha (2006), the application of this approach will expose students to complex activities such as creating relationships, reflecting, asking and answering questions, describing the content of the lesson, discussing, solving problems, constructing ideas, analyzing and synthesizing ideas. According to Brainer (1999), students build their knowledge by testing ideas and approaches based on existing knowledge and experience, and then apply it in new situations as well as integrate new knowledge acquired by existing intellectual construction. The basic principle in this constructivist learning is the knowledge built by the students themselves which each student has their ideas and knowledge base, knowledge construction process that involve the social aspect, and a teacher as a facilitator in the construction of students' knowledge (Zakaria, 2015). Constructivism is an approach that focuses on how people learn (Mc Brien \& Brandt, 1997). According to Brooks and Brooks (1993), this theory states that students construct the meaning about their world as well as process new experiences to what they understand before. According to Yang (2001), there are two main branches of the constructivism theory which are cognitive and social aspects. Constructivism is a cognitive theory that believes in exploration i.e. curiosity of knowledge, while social constructivism applies in situations where the knowledge and experience shared. Therefore, many researchers (Zakaria, 2015; Sutisna, 2013; Halim \& Lai, 2013; Amin, Fadila, \& Zulkifli, 2010 and Munip, 2012) have recommended this theory of constructivism in teaching and learning process as the ability to increase readiness of the students themselves.

Many studies have been conducted related to teaching aids based on the theory of constructivism. The studies conducted are mostly to find out the effectiveness and the suitability of learning through instructional design methods based on constructivism. According to a study conducted by Hashim and Razali Jantan (2003), the use of teaching aids when teaching the students can give them an emphasis to be more active and to incorporate new knowledge acquired by the existing experience in their minds and to apply what is understood in various situations. In addition, a research conducted by Ambatong et al., (2011), teaching aids development will be able to stimulate students' interest and it is appropriate to the concept of constructivist theory of knowledge which states that the knowledge cannot exist outside the mind of students but it is built within the actual experience by students. Teaching aids are built to meet the quality standards of the aspects of learning theory such as constructivism theory as well as to fulfil something in a learning process (Bajraktarevic et al., 2003). Nik Azis (1999) 
said the use of constructivism learning can help students in process of receiving new information and knowledge which students can remember something that means something to them.

According to Ibrahim (2008), constructivism learning in teaching aids can help students to solve problems more quickly because the process is emphasized on the aspect of thinking and discussion in a group that are able to create a two-way communication between students and teachers, and students and students. In addition, Ibrahim and Redwan (2010) suggested the use of constructivist learning theory in teaching aids has the advantage to produce a meaningful learning. Therefore, the application of the theory of constructivism in the learning process such as the use of teaching aids, can benefit the students positively and give a good impact to the development of students. Eventually, that will help students to possess a deeper memory and a clearer understanding of the learning content in a classroom.

\section{Methodology}

This study used quantitative approach to look at the effects of using programmable logic controller learning kit on the achievement of the students in the control system module. The study applied quasi-experimental framework and adopted a non-equivalent control group design such as Table 1. The experimental design was selected to evaluate the effectiveness of treatment groups and control groups of non-random responders (Campbell \& Stanley, 1963 This design was chosen because the researchers could not predict whether respondents are in treatment or control group.

Table 1. Pre and post test designs

\begin{tabular}{cccc}
\hline Group & Pre Test & Treatment & Post Test \\
\hline Experiment & $\mathrm{T} 1$ & $\mathrm{X}$ & $\mathrm{T} 2$ \\
\hline Control & $\mathrm{T} 2$ & & $\mathrm{~T} 2$ \\
\hline
\end{tabular}

This design was chosen because the researchers wanted to see the effects of two types of teaching methods towards the students. The experimental group used programmable logic controller learning kit, while the controlled group was taught by using a conventional method. By using this design, the impact of the use of programmable logic controller kit and effects of the conventional method will be determined by comparing the scores of pre and post-test (T1, T2).

\subsection{Respondents}

The sample was selected in order to find out students' achievement data scores after pre-test and post-test. The sample was not a probability sample because the sample selected was an existing sample. According to Creswell (2012), the minimum sample size that can be received is 10 percent, but if it is from a small population, a sample of 15 people in a group will be sufficient for an experimental study.

Table 2 shows the total sample population for the two groups, the controlled group and the treatment group. The total sample for this study was 60 which was divided into treatment group (30 students) and control group (30 students).

Table 2. Fourth year student group

\begin{tabular}{ccc}
\hline & Control Group & Experiment Group \\
\hline Population & 130 orang & 130 orang \\
\hline Sample & 30 orang & 30 orang \\
\hline
\end{tabular}

\subsection{Instruments}

According to Abdul Ghafar (1999), an instrument is a measurement tool to measure the behavior or the behavior of human beings or objects that are not humane. The instrument used is important to determine the type of data collected and it will influence the type of analysis of the researcher (Mohd Majid Konting, 1990). Two important criteria in establishing validity and reliability of the instrument are related to the instruments used. The instruments will be used in this study are a questionnaire and pre-test and post-test questions.

A pre-test questionnaire was given before the experiment was conducted. Pre-test included 3 sections of questions on the programmable logic controller topic. It was provided for the students to test their prior knowledge about the topic. The use of objective and subjective questions is to facilitate students in answering questions that have been documented. The developed test has three difficulty levels, namely low, medium, and high. Every question has a mark that was set. The objective questions aimed to reduce stress and time of respondents to answer the question (Ab. Halim \& Lai, 2011). The time given to answer was one hour.

A post-test was carried out in a given period after the experiment. There were similar questions in both pre and post-test, however the questions were arranged differently. Post-test was carried out shortly after treatment was given. The treatment group is the group that used the programmable logic controller learning kit. The period between pre and post-test was three months. The difference between pre and post-test scores will determine the effectiveness of the programmable logic controller learning kit. This is to measure the level of students' achievement in the control system module.

Table 3. List of contents of student questionnaire

\begin{tabular}{ccc}
\hline Item & Perkara & Scale \\
\hline B1 & Functionality aspect & Likert-5 \\
\hline B2 & Design aspect & Likert-5 \\
\hline B3 & Suitability aspect & Likert-5 \\
\hline
\end{tabular}

Another instrument used in this study was a questionnaire form which was divided into three parts related to functionality, design aspects of teaching aids, and 
adaptability based on Table 3. The purpose of this questionnaire is to get feedback from students on kit developed. The use of this questionnaire can improve the accuracy and correctness of the development of programmable logic controller kit, either it could be appropriate for use in the process of the learning.

\section{Results and Findings}

Data collected through the pre-test, post-test, and a questionnaire will determine the effectiveness of developed learning kit. After conducting a research, collecting data is needed for the purpose of analysis. For this study, the data were analyzed by using descriptive statistics, percentage, Likert scale, mean and t-test. A comparative analysis was carried out between the control group and the treatment to see whether there are differences in effectiveness between the two methods of teaching or not.

\subsection{Score Mean for Treatment and Control Groups}

To determine whether students from the two groups, the control and treatment groups, are at the same level in terms of their knowledge related to the programmable logic controller topic, a pre-test was used. From Table 4, the mean value of the control group was 35.27 and the treatment group is 37.57. To analyse the significant differences that exist between the two groups, the researchers used t test of independent samples. Table 4 shows that the Sig. (2-tailed) between the two groups was not significant, namely 0.333 and 0.334 , higher than $<0.05$. Thus, we can conclude that the two groups did not have much difference in terms of their performance in the pre-test.

These results indicate that samples used in this study have an equivalent level of performance for both groups (control and treatment). This is because retrieval vocational college students have been through the same stages of learning everywhere throughout Malaysia Vocational College, through their PT3 results. Furthermore, the programmable logic controller topic is a difficult topic in control system module, so the knowledge samples for both groups are similar and are based upon their existing knowledge in vocational college. To conclude, both groups have the same academic level.

After treatment, both groups took a post-test. As noted earlier, a similar test will be administered as a post-test to evaluate the effectiveness of the learning kit that was developed. Through Table 4, the mean value of the control group is 42.37 and for the treatment group is 55.77. The treatment group achieved higher scores than the control group. To see some significant differences that exist between the two groups, the researchers used the $t$ test of independent samples. Table 4 shows the Sig. (2-tailed) between the two groups is significant, namely 0.000 which is less $<0.05$. It can be concluded that there is a significant difference in students' post-test results for the control and treatment groups.

The treatment group has a higher mean value than the control group for the post-test. This situation illustrates the use of teaching aids that could be effective in improving students' achievement in the post-test compared to those who were exposed to traditional methods. The use of teaching aids is an effective method to teach the control system modules because these modules are mostly using the actual equipment. Students can understand better when the learning involves real equipment. This is supported by a study conducted by Hastuti, Effendi and Hijriani, (2017); Mat Saat and Abbas, (2016); Pathmantara, Wibawa and Rahyu, (2015); Mohd Isa, (2012); Ahmad and Tamuri, (2010), which mentioned that an instruction in the classroom requires the support of real media material. The use of teaching aids is able to increase students' understanding of a topic and is able to raise the level of students' achievement. The finding is supported by Hastuti, Effendi and Hijriani, (2017); Mat Saat and Abbas, (2016); Halim and Lai, (2013); Ahmad and Tamuri, (2010) which stated that with the help of supporting materials such as teaching aids, to some extent, can help teachers to provide a deeper understanding to students who have less knowledge in terms of academic achievement.

Table 4. Score on pre and post exam

\begin{tabular}{ccccccccccc}
\hline \multirow{2}{*}{ Stage } & Group & $\mathrm{N}$ & Mean & $\begin{array}{c}\text { Std. } \\
\text { Deviation }\end{array}$ & $\begin{array}{c}\text { Std. Eror } \\
\text { Mean }\end{array}$ & $\begin{array}{c}\text { Sig. } \\
(2-t a i l e d)\end{array}$ \\
\hline \multirow{2}{*}{ Pre } & Control & 30 & 35.27 & 10.954 & 2.000 & -0.977 & 58 & 0.333 \\
& Experiment & 30 & 37.57 & 6.806 & 1.243 & -0.977 & 48.486 & 0.334 & -6.330 & 58 \\
\multirow{2}{*}{ Post } & Control & 30 & 42.37 & 7.337 & 1.339 & 0.000 & -6.330 & 55.787 \\
& Experiment & 30 & 55.77 & 8.978 & 1.639 & 0.000 \\
\hline
\end{tabular}




\subsection{The Difference between the Control Group and the Treatment Group}

This test consists of two main parts, namely the control group and the treatment group. A $\mathrm{t}$ test for repeated measurements was applied to see how they performed in pre and post-test.

Table 6 shows the difference in the mean values for the control group, 7.100. In addition, the findings of paired samples $t$ test reflect that the control group has a significant value at the level of 0.00 , which is less than $<0.05$. It can be concluded, that there is a difference in the results for students in the control group for their pre and post-test.

This data shows an increase in post-test, even by using traditional methods. This is due to the teacher who used all the information and facts contained in the module to explain the concepts and facts about the programmable logic controller. However, the pattern of service teacher plays an important role to ensure that the students understand the lesson that was conveyed. This assertion is supported by Abdullah and Ahmad (2017) that every teacher should have a facilitator or facilitators to diversify teaching methods, so they can maximize their learning in the classroom to achieve learning objectives.

Table 5. Paired sample statistics

\begin{tabular}{cccccc}
\hline Group & Test & $\mathrm{N}$ & Mean & $\begin{array}{c}\text { Std. } \\
\text { Deviation }\end{array}$ & $\begin{array}{c}\text { Std. Eror } \\
\text { Mean }\end{array}$ \\
\hline \multirow{2}{*}{ Control } & Pre & 30 & 35.27 & 10.954 & 2.000 \\
& Post & 30 & 42.37 & 7.337 & 1.339 \\
\hline
\end{tabular}

Table 6. The difference between control group

\begin{tabular}{|c|c|c|c|c|c|c|c|c|c|}
\hline \multirow[t]{2}{*}{ Group } & \multirow[t]{2}{*}{ Test } & \multirow[t]{2}{*}{ Mean } & \multirow{2}{*}{$\begin{array}{c}\text { Std. } \\
\text { Deviation }\end{array}$} & \multirow{2}{*}{$\begin{array}{l}\text { Std. Eror } \\
\text { Mean }\end{array}$} & \multicolumn{2}{|c|}{$\begin{array}{c}95 \% \\
\text { Interveral difference }\end{array}$} & \multirow[t]{2}{*}{$\mathrm{t}$} & \multirow[t]{2}{*}{$\mathrm{df}$} & \multirow[t]{2}{*}{ Sig. (2-tailed) } \\
\hline & & & & & Lower & Upper & & & \\
\hline Control & $\begin{array}{l}\text { Pre } \\
\text { Post }\end{array}$ & -7.100 & 9.144 & 1.669 & -10.514 & -3.686 & -4.253 & 29 & 0.000 \\
\hline
\end{tabular}

\subsection{The Difference between the Experiment Groups}

Table 7. Paired sample statistics

\begin{tabular}{cccccc}
\hline Group & Test & \multirow{N}{*}{} & \multirow{2}{*}{ Mean } & $\begin{array}{c}\text { Std. } \\
\text { Deviation }\end{array}$ & $\begin{array}{c}\text { Std. Eror } \\
\text { Mean }\end{array}$ \\
\hline \multirow{2}{*}{ Experiment } & Pre & 30 & 37.57 & 6.806 & 1.243 \\
& Post & 30 & 55.77 & 8.978 & 1.639 \\
\hline
\end{tabular}

Table 8. The difference between control group

\begin{tabular}{|c|c|c|c|c|c|c|c|c|c|}
\hline \multirow{2}{*}{ Group } & \multirow[t]{2}{*}{ Test } & \multirow[t]{2}{*}{ Mean } & \multirow{2}{*}{$\begin{array}{c}\text { Std. } \\
\text { Deviation }\end{array}$} & \multirow{2}{*}{$\begin{array}{l}\text { Std. Eror } \\
\text { Mean }\end{array}$} & \multicolumn{2}{|c|}{$\begin{array}{c}95 \% \\
\text { Interval difference }\end{array}$} & \multirow[t]{2}{*}{$\mathrm{t}$} & \multirow[t]{2}{*}{ df } & \multirow{2}{*}{ Sig. (2-tailed) } \\
\hline & & & & & Lower & Upper & & & \\
\hline Experiment & $\begin{array}{l}\text { Pre } \\
\text { Post }\end{array}$ & -18.200 & 11.294 & 2.062 & -22.417 & -13.983 & -8.827 & 29 & 0.000 \\
\hline
\end{tabular}


Table 8 shows the difference mean for the treatment group i.e. 18,200. In addition, the findings of paired samples $t$ test show that the treatment group has a significant value at 0.00 level which is less than $<0.05$. It can be concluded, that there is a difference in the results among students in the treatment group pre and post-test.

Teaching and learning session with assistance from teaching aids increased students' understanding. The importance of systematic teaching using teaching aids has been declared by (Mat Saat \& Abbas, 2016). By using teaching aids, students can learn in stages according to their abilities, for example from easy to difficult.

Overall, the findings obtained for this study matched the findings obtained by Abdullah, Abidin, and Mohamad (2013) in his study of teaching aids as teaching and learning methods for magnetic control topics. In that study, students that were treated with the use of the teaching aids showed a significant difference in scores between students who were taught using traditional methods. This shows that the use of teaching aids in learning and teaching is definitely effective.

\subsection{Questionnaire}

30 students from the treatment group were given questionnaire in the last week of using the kit. The students were told to answer questions carefully. The students were asked to answer all the questions by following given scale of 1 to 5 . Scale 1 means students strongly disagree with the statement and the scale of 5 means that students strongly agree with the statement.

According to Table 9, it was found that the highest variable mean is 5.00 which represents almost all items except item 9 in functionality aspect, with the interpretation of the mean being high. 30 respondents gave "strongly agree" answer for functional reliability items. The lowest mean is 4.37 that represents item 9. Although the mean values are low but the interpretation of the mean is classified as a high-level interpretation min. There are 11 respondents who gave "strongly agree" answer and a total of 19 respondents responded "agree" answer.

Table 9. Functionality

\begin{tabular}{|c|c|c|c|c|c|c|c|}
\hline No Item functionality & $\mathbf{N}$ & Min & $\begin{array}{c}\text { Strongly } \\
\text { disagree } \\
\% \\
\end{array}$ & $\begin{array}{l}\text { Disagree } \\
\%\end{array}$ & $\begin{array}{l}\text { Neutral } \\
\%\end{array}$ & $\begin{array}{l}\text { Agree } \\
\%\end{array}$ & $\begin{array}{c}\text { Strongly } \\
\text { agree } \\
\% \\
\end{array}$ \\
\hline Power supply unit can work when the supply is switched on. & 30 & 5.00 & $\begin{array}{c}0 \\
(0.0) \\
\end{array}$ & $\begin{array}{c}0 \\
(0.0)\end{array}$ & $\begin{array}{c}0 \\
(0.0)\end{array}$ & $\begin{array}{c}0 \\
(0.0)\end{array}$ & $\begin{array}{c}30 \\
(100.0)\end{array}$ \\
\hline PLC unit can work when the supply is switched on. & 30 & 5.00 & $\begin{array}{c}0 \\
(0.0)\end{array}$ & $\begin{array}{c}0 \\
(0.0)\end{array}$ & $\begin{array}{c}0 \\
(0.0)\end{array}$ & $\begin{array}{c}0 \\
(0.0)\end{array}$ & $\begin{array}{c}30 \\
(100.0)\end{array}$ \\
\hline Push-button functions when pressed. & 30 & 5.00 & $\begin{array}{c}0 \\
(0.0)\end{array}$ & $\begin{array}{c}0 \\
(0.0)\end{array}$ & $\begin{array}{c}0 \\
(0.0)\end{array}$ & $\begin{array}{c}0 \\
(0.0)\end{array}$ & $\begin{array}{c}30 \\
(100.0)\end{array}$ \\
\hline Lighting can work when turned on and off. & 30 & 5.00 & $\begin{array}{c}0 \\
(0.0)\end{array}$ & $\begin{array}{c}0 \\
(0.0)\end{array}$ & $\begin{array}{c}0 \\
(0.0)\end{array}$ & $\begin{array}{c}0 \\
(0.0)\end{array}$ & $\begin{array}{c}30 \\
(100.0)\end{array}$ \\
\hline $\begin{array}{l}\text { Detectors (sensors) can function when detecting a moving facing } \\
\text { material. }\end{array}$ & 30 & 5.00 & $\begin{array}{c}0 \\
(0.0)\end{array}$ & $\begin{array}{c}0 \\
(0.0)\end{array}$ & $\begin{array}{c}0 \\
(0.0) \\
\end{array}$ & $\begin{array}{c}0 \\
(0.0)\end{array}$ & $\begin{array}{c}30 \\
(100.0)\end{array}$ \\
\hline The motor can rotate. & 30 & 5.00 & $\begin{array}{c}0 \\
(0.0)\end{array}$ & $\begin{array}{c}0 \\
(0.0)\end{array}$ & $\begin{array}{c}0 \\
(0.0)\end{array}$ & $\begin{array}{c}0 \\
(0.0)\end{array}$ & $\begin{array}{c}30 \\
(100.0)\end{array}$ \\
\hline Touch can work when turned on. & 30 & 5.00 & $\begin{array}{c}0 \\
(0.0) \\
\end{array}$ & $\begin{array}{c}0 \\
(0.0) \\
\end{array}$ & $\begin{array}{c}0 \\
(0.0) \\
\end{array}$ & $\begin{array}{c}0 \\
(0.0) \\
\end{array}$ & $\begin{array}{c}30 \\
(100.0) \\
\end{array}$ \\
\hline Traffic lights can work in sequence. & 30 & 5.00 & $\begin{array}{c}0 \\
(0.0)\end{array}$ & $\begin{array}{c}0 \\
(0.0)\end{array}$ & $\begin{array}{c}0 \\
(0.0)\end{array}$ & $\begin{array}{c}0 \\
(0.0)\end{array}$ & $\begin{array}{c}30 \\
(100.0)\end{array}$ \\
\hline Conveyors can rotate well. & 30 & 4.37 & $\begin{array}{c}0 \\
(0.0)\end{array}$ & $\begin{array}{c}0 \\
(0.0)\end{array}$ & $\begin{array}{c}0 \\
(0.0)\end{array}$ & $\begin{array}{c}19 \\
(63.3)\end{array}$ & $11(36.7)$ \\
\hline This kit can be powered by either & 30 & 5.00 & $\begin{array}{c}0 \\
(0.0) \\
\end{array}$ & $\begin{array}{c}0 \\
(0.0) \\
\end{array}$ & $\begin{array}{c}0 \\
(0.0) \\
\end{array}$ & $\begin{array}{c}0 \\
(0.0) \\
\end{array}$ & $\begin{array}{c}30 \\
(100.0) \\
\end{array}$ \\
\hline The circuit is built to work with the software CX-Programmer & 30 & 5.00 & $\begin{array}{c}0 \\
(0.0)\end{array}$ & $\begin{array}{c}0 \\
(0.0)\end{array}$ & $\begin{array}{c}0 \\
(0.0)\end{array}$ & $\begin{array}{c}0 \\
(0.0)\end{array}$ & $\begin{array}{c}30 \\
(100.0)\end{array}$ \\
\hline
\end{tabular}


According to Table 10, it was found that the highest variable mean is 5.00 which represents the first item, sixth, seventh, eighth and tenth, with a mean interpretation being high. There are 30 respondents who strongly agreed on this item.
The lowest mean is 4.67, which represents the ninth item. Although the mean values are low but the interpretation of the mean is classified as a high-level interpretation min. There are 20 respondents who gave answer "strongly agree" and a total of 10 respondents also agreed.

Table 10. Design

\begin{tabular}{|c|c|c|c|c|c|c|c|}
\hline No Item Design & $\mathbf{N}$ & Min & $\begin{array}{c}\text { Strongly } \\
\text { disagree } \\
\%\end{array}$ & $\begin{array}{c}\text { Disagree } \\
\%\end{array}$ & $\begin{array}{c}\text { Neutral } \\
\%\end{array}$ & $\begin{array}{c}\text { Agree } \\
\%\end{array}$ & $\begin{array}{c}\text { Strongly } \\
\text { agree } \\
\%\end{array}$ \\
\hline This design has the size that fits a student internship. & 30 & 5.00 & $\begin{array}{c}0 \\
(0.0)\end{array}$ & $\begin{array}{c}0 \\
(0.0)\end{array}$ & $\begin{array}{c}0 \\
(0.0)\end{array}$ & $\begin{array}{c}0 \\
(0.0)\end{array}$ & $30(100.0)$ \\
\hline The design of the components and kits are labeled clearly & 30 & 4.87 & $\begin{array}{c}0 \\
(0.0)\end{array}$ & $\begin{array}{c}0 \\
(0.0)\end{array}$ & $\begin{array}{c}0 \\
(0.0)\end{array}$ & $\begin{array}{c}4 \\
(13.3)\end{array}$ & $\begin{array}{c}26 \\
(86.7)\end{array}$ \\
\hline This design has a regular component layout. & 30 & 4.97 & $\begin{array}{c}0 \\
(0.0)\end{array}$ & $\begin{array}{c}0 \\
(0.0)\end{array}$ & $\begin{array}{c}0 \\
(0.0)\end{array}$ & $1(3.3)$ & $\begin{array}{c}29 \\
(96.7)\end{array}$ \\
\hline This design is stable and strong. & 30 & 4.90 & $\begin{array}{c}0 \\
(0.0)\end{array}$ & $\begin{array}{c}0 \\
(0.0)\end{array}$ & $\begin{array}{c}1 \\
(3.3)\end{array}$ & $\begin{array}{c}1 \\
(3.3)\end{array}$ & 28 (93.3) \\
\hline This design has good insulation properties. & 30 & 4.87 & $\begin{array}{c}0 \\
(0.0)\end{array}$ & $\begin{array}{c}0 \\
(0.0)\end{array}$ & $\begin{array}{c}0 \\
(0.0)\end{array}$ & $\begin{array}{c}4 \\
(13.3)\end{array}$ & $26(86.7)$ \\
\hline This design is easy to store. & 30 & 5.00 & $\begin{array}{c}0 \\
(0.0)\end{array}$ & $\begin{array}{c}0 \\
(0.0)\end{array}$ & $\begin{array}{c}0 \\
(0.0)\end{array}$ & $\begin{array}{c}0 \\
(0.0)\end{array}$ & $30(100.0)$ \\
\hline $\begin{array}{l}\text { The design features a framework that can be used by teachers } \\
\text { and students. }\end{array}$ & 30 & 5.00 & $\begin{array}{c}0 \\
(0.0)\end{array}$ & $\begin{array}{c}0 \\
(0.0)\end{array}$ & $\begin{array}{c}0 \\
(0.0)\end{array}$ & $\begin{array}{c}0 \\
(0.0)\end{array}$ & $30(100.0)$ \\
\hline This design is easy to carry. & 30 & 5.00 & $\begin{array}{c}0 \\
(0.0)\end{array}$ & $\begin{array}{c}0 \\
(0.0)\end{array}$ & $\begin{array}{c}0 \\
(0.0)\end{array}$ & $\begin{array}{c}0 \\
(0.0)\end{array}$ & $30(100.0)$ \\
\hline This design uses a durable building material. & 30 & 4.67 & $\begin{array}{c}0 \\
(0.0)\end{array}$ & $\begin{array}{c}0 \\
(0.0)\end{array}$ & $\begin{array}{c}0 \\
(0.0)\end{array}$ & $\begin{array}{c}10 \\
(33.3)\end{array}$ & $20(66.7)$ \\
\hline $\begin{array}{l}\text { This design has safety features such as warning signs and } \\
\text { warnings. }\end{array}$ & 30 & 5.00 & $\begin{array}{c}0 \\
(0.0)\end{array}$ & $\begin{array}{c}0 \\
(0.0)\end{array}$ & $\begin{array}{c}0 \\
(0.0)\end{array}$ & $\begin{array}{c}0 \\
(0.0)\end{array}$ & $30(100.0)$ \\
\hline
\end{tabular}

Table11. Suitability

\begin{tabular}{|c|c|c|c|c|c|c|c|}
\hline No Item suitability & $\mathbf{N}$ & Min & $\begin{array}{c}\text { Strongly } \\
\text { disagree } \\
\% \\
\end{array}$ & $\begin{array}{c}\text { Disagree } \\
\%\end{array}$ & $\begin{array}{c}\text { Neutral } \\
\%\end{array}$ & $\begin{array}{c}\text { Agree } \\
\%\end{array}$ & $\begin{array}{c}\text { Strongly } \\
\text { agree } \\
\% \\
\end{array}$ \\
\hline This kit can help as teaching aids in the classroom. & 30 & 4.87 & $\begin{array}{c}0 \\
(0.0)\end{array}$ & $\begin{array}{c}0 \\
(0.0)\end{array}$ & $\begin{array}{c}0 \\
(0.0)\end{array}$ & $\begin{array}{c}4 \\
(13.3)\end{array}$ & $\begin{array}{c}26 \\
(86.7)\end{array}$ \\
\hline This kit can help as teaching aids in practice. & 30 & 4.93 & $\begin{array}{c}0 \\
(0.0)\end{array}$ & $\begin{array}{c}0 \\
(0.0)\end{array}$ & $\begin{array}{c}0 \\
(0.0)\end{array}$ & $\begin{array}{c}2 \\
(6.7)\end{array}$ & $\begin{array}{c}28 \\
(93.3) \\
\end{array}$ \\
\hline This kit was developed relevant to students taking modules DEA3323 & 30 & 4.77 & $\begin{array}{c}0 \\
(0.0)\end{array}$ & $\begin{array}{c}0 \\
(0.0)\end{array}$ & $\begin{array}{c}0 \\
(0.0)\end{array}$ & $\begin{array}{c}7 \\
(23.3)\end{array}$ & $\begin{array}{c}23 \\
(76.7)\end{array}$ \\
\hline These kits can help improve my understanding of the control system. & 30 & 5.00 & $\begin{array}{c}0 \\
(0.0)\end{array}$ & $\begin{array}{c}0 \\
(0.0)\end{array}$ & $\begin{array}{c}0 \\
(0.0)\end{array}$ & $\begin{array}{c}0 \\
(0.0)\end{array}$ & $\begin{array}{c}30 \\
(100.0)\end{array}$ \\
\hline This kit can help attract me to follow the teaching and learning process & 30 & 4.90 & $\begin{array}{c}0 \\
(0.0) \\
\end{array}$ & $\begin{array}{c}0 \\
(0.0)\end{array}$ & $\begin{array}{c}0 \\
(0.0)\end{array}$ & $\begin{array}{c}3 \\
(10.0) \\
\end{array}$ & $\begin{array}{c}27 \\
(90.0) \\
\end{array}$ \\
\hline This kit can save time during the internship process that is carried out & 30 & 4.97 & $\begin{array}{c}0 \\
(0.0)\end{array}$ & $\begin{array}{c}0 \\
(0.0)\end{array}$ & $\begin{array}{c}0 \\
(0.0)\end{array}$ & $\begin{array}{c}1 \\
(3.3)\end{array}$ & $\begin{array}{c}29 \\
(96.7)\end{array}$ \\
\hline This kit is easy to operate. & 30 & 4.27 & $\begin{array}{c}0 \\
(0.0) \\
\end{array}$ & $\begin{array}{c}0 \\
(0.0) \\
\end{array}$ & $\begin{array}{c}1 \\
(3.3) \\
\end{array}$ & $\begin{array}{c}20 \\
(66.7) \\
\end{array}$ & $9(30.0)$ \\
\hline These kits help me in my understanding of the control system. & 30 & 4.87 & $\begin{array}{c}0 \\
(0.0)\end{array}$ & $\begin{array}{c}0 \\
(0.0)\end{array}$ & $\begin{array}{c}0 \\
(0.0)\end{array}$ & $\begin{array}{c}4 \\
(0.0)\end{array}$ & $\begin{array}{c}26 \\
(86.7)\end{array}$ \\
\hline $\begin{array}{l}\text { This kit is easier to understand if used together with a set of practical } \\
\text { and manual use. }\end{array}$ & 30 & 4.97 & $\begin{array}{c}0 \\
(0.0)\end{array}$ & $\begin{array}{c}0 \\
(0.0)\end{array}$ & $\begin{array}{c}0 \\
(0.0)\end{array}$ & $\begin{array}{c}1 \\
(3.3)\end{array}$ & $\begin{array}{c}29 \\
(96.7)\end{array}$ \\
\hline
\end{tabular}


According to Table 11, it was found that the highest variable mean is 5.00 which represents fourth item, with the interpretation of the mean being high. There are 30 respondents who gave answer "strongly agree" on this item. The lowest mean is 4.27 which represents the seventh item. Although the mean values are low but the interpretation of the mean is classified as a high-level interpretation min. There are 9 respondents who gave answer "strongly agree" and some 20 respondents responded "agree". In addition, a total of 1 respondent gave "neutral" response.

\section{Discussion and Conclusions}

The conclusion that can be drawn from this study is the use of teaching aids can improve students' achievement. Thus, the initial hypothesis in this study was rejected. The use of the proven teaching aids can be efficient and have a significant impact to teaching and learning process. Students are taught by using teaching aids, so they can be enthusiastic and keen to learn programmable logic controller topic, compared to students who are taught using conventional methods. Students can focus more and pay full attention when teaching aids are introduced into teaching and learning environment. Using teaching aids in teaching is one of the proven methods of teaching to increase students' achievement. The diversity of approaches adopted by teachers such as teaching aids consumption is encouraged so that students will be more interested in control system module and eventually remove their negative response to the control system module

\section{Acknowledgements}

This research project is supported by the Faculty of Technical Education Universiti Tun Hussein Onn Malaysia.

\section{REFERENCES}

[1] Ab Halim, H. H. \& Lai, C. S. (2011). Penilaian Keberkesanan Kit Pengajaran Transistor Bagi Aliran Vokasional. Seminar Pasca Ijazah yang Pertama, pp 615.

[2] Abdul Ghafar, M. N. (1999). Penyelidikan Pendidikan. Skudai: UTM Press.

[3] Abdullah, S., \& Ahmad, N. S. (2017). Keberkesanan Aplikasi Youtube Dalam Pengajaran dan Pembelajaran Sains Kejuruteraan di Politeknik Seberang Perai. e Proc National Innovation and Invention Competiotion Through Exhibition, pp 1-8.

[4] Abdullah, N. A. S., Zakaria, N., Suaji, M. A. (2016). Keberkesanan Penggunaan ABBM bagi Modul Elektronik di Kolej Vokasioanal. Proc of the First National Conference on TVET. JPK, FPTV: Universiti Tun Hussein Onn Malaysia. pp. 77-83.
[5] Abidin, R. Z. \& Jamaat, A. (2016). Model "Elektromagnetik" Sebagai Alat Bahan Bantu Mengajar (ABBM). Proc of the First National Conference on TVET. JPK, FPTV: Universiti Tun Hussein Onn Malaysia. pp. 345-356.

[6] Ahmad, S. F. \& Tamuri, A. H. (2010). Persepsi Guru Terhadap Penggunaan Bahan Bantu Mengajar Berasaskan Teknologi Multimedia Dalam Pengajaran j-QAF. Journal of Islamic and Arabic Education, 2(2), 53-64.

[7] Alias, N., Ahmad, A., Soowan, P. (2017). Kajian Keberkesanan Terhadap Kit Amali Peranti Separa Pengalir Bagi Subjek DET5073-Power Electronics. e Proceeding National Innovation and Invention Competition Through Exhibition 2017.

[8] Ambotang, A. S, Mohamad, B., Abdullah, M. Y., Salleh, M. J. \& Francis, N. (2011). Keberkesanan Penggunaan Model Bentuk Muka Bumi Sungai bagi MeningkatkanPrestasi Pelajar dalam Matapelajaran Geografi Tingkatan 1. Proc.National Conference on History and Geography Education. Kota Kinabalu: Universiti Malaysia Sabah. pp $1-12$.

[9] Amin, M., Fadila, N., \& Zulkifli, E. (2010). Pembangunan Perisian Multimedia Berkonsepkan Teori Konstruktivisme Bagi Lukisan Tangen. Teori Konstruktivisme Bagi

[10] Bajraktarevic, N., Hall, W., \& Fullick, P. (2003). Incorporating Learning Styles In Hypermedia Environment: Empirical Evaluation. Proceedings of AH2003: Workshop on Adaptive Hypermedia and Adaptive Web-Based Systems.

[11] Briner, M. (1999). What is Constructivism?. University of Colorado at Denver School of Education.

[12] Brooks, J. G. \& Brooks, M. G. (1993). In search of understanding: the case for constructivist classroom. Alexandria, VA; Association for Supervision and Curriculum Development.

[13] Buntat, Y. \& Mohamad, N. A. M. (2010). Keberkesanan Penggunaan Alat Bantu Mengajar Berbantukan Komputer Dalam Pengajaran dan Pembelajaran Subjek Kemahiran Hidup (KH) di Sekolah Menengah Kebangsaan Agama Kedah, Alor Star, Kedah. Universiti Teknologi Malaysia.

[14] Campbell, D. \& Stanley, J. (1963). Experimental and Quasiexperimental Designs for Research. Chicago, IL: RandMcNally.

[15] Creswell, J. W. (2012). Educational research: Planning, conducting, and evaluating quantitative and qualitative research. Educational Research (Vol. 3).

[16] Febriyanto. (2015). Efektivitas Pembelajaran Berbasis Masalah Berbantuan Trainer Human Machine Interface Untuk Peningkatan Kompetensi Perakitan Sistem PLC SMK N 2 Depok. Universitas Negeri Yogyakarta: Tesis Sarjana.

[17] Hamdan, A. R. \& Ayop, A. F. (2010). Kesesuaian Isi Kandungan, Masa, Kemudahan dan Alatan, dan Kaedah Tunjukcara (Demonstrasi) Dalam Matapelajaran Kemahiran Teknikal Peringkat Menengah Rendah Dari Perspektif Guru-Guru Kemahiran Hidup di Sekolah Menengah di Daerah Kluang. Universiti Teknologi Malaysia.

[18] Hashim, S., Razali, M. \& Jantan, R. (2003). Psikologi Pendidikan. Pahang: PTS Publication.

[19] Hastuti, Effendi, H., Hijriani, S. (2017). Penerapan Trainer 
PLC Omron Sebagai Media Pembelajaran Mata Diklat Instalasi Motor Listrik. Invotek, 17(1), 49-56.

[20] Ibrahim, I. (2008). Pembelajaran Konstruktivisme Melalui Penghasilan Video oleh Pelajar Universiti Tun Hussein Onn Malaysia. Universiti Tun Hussein Onn Malaysia: Tesis Sarjana.

[21] Ibrahim, M. A dan Redwan, A. S (2010). Pembangunan Perisian Pengajaran Berasaskan Model Konstruktif Needham 5 Fasa Bagi Tajuk Keelektrikan Dalam Matapelajaran Sains Sekolah Rendah. Fakulti Pendidikan: Universiti Teknologi Malaysia.

[22] Jasmi, K. A., Ilias, M. F., Tamuri, A. H. \& Mohd Hamzah, M. I. (2011). Amalan Penggunaan Bahan Bantu Mengajar dalam Kalangan Guru Cemerlang Pendidikan Islam Sekolah Menengah di Malaysia. Journal of Islamic and Arabic Education, 3(1), 59-74.

[23] Kementerian Pendidikan Malaysia (2013). Pelan Pembangunan Pendidikan Malaysia 2013-2025. Putrajaya: KPM.

[24] Kurniawan, W. D., Samani, M. \& Soeryanto. (2013). Pengembangan Perangkat Pembelajaran Mekatronik Berbasis Komputer Pokok Bahasan Programmable Logic Controller Berorientasi Pada Pembelajaran Langsung. Jurnal Pendidikan Vokasi: Teori Dan Praktek, 1(1). 9-16.

[25] Madar, A. R., Mazlan, S. N. A., Rahim, M. R., Mustafa, M. Z. (2009). Educational Multifunctional Electronic Robotic Kit. Seminar Kebangsaan Pendidikan Teknik dan Vokasional, 3, 1-19.

[26] Mat Saat, S. N. \& Abbas, L. N. (2016). Kit Pengajaran Sistem Bekalan Air Domestik Sebagai Alat Bahan Bantu Mengajar (Abbm). Proc of the First National Conference on TVET. JPK, FPTV: Universiti Tun Hussein Onn Malaysia. pp. 383-390.

[27] Martha C. (2006). Implementing Constructivist Web-Based Learning and Determining its Effectiveness on a Teacher Preparation Course. Journal of Educators Online. 3(2).

[28] McBrien, J. L., and Brandt, R. S. (1997). The language of learning: A guide to education terms. Alexandria, VA: Association for Supervision and Curriculum Development.

[29] Mohd Isa, N. R. (2012). Kesan Penggunaan Educational Multifunctional Programmable Logic Controller Kit Terhadap Pencapaian Pelajar Yang Berbeza Gaya Kognitif. Universiti Tun Hussein Onn Malaysia: Tesis Sarjana.

[30] Mohd Nor, A. \& Sharif, S. (2014). Penggunaan Bahan Visual di Kalangan Guru Teknikal. Journal for Educational Thinkers, Vol 5, 79-98.

[31] Munip, H. (2012). Aplikasi Pendekatan Konstruktivisme Dalam Reka Bentuk Pengajaran Berasaskan Komputer: Pengaruhnya Terhadap Pencapaian Berdasarkan Aras Kognitif Pelajar. Persidangan Kebangsaan Pembangunan Dan Pendidikan Lestari 2012, (September), 100-118.

[32] Musa, N. E. \& Mohamad, M. H. (2014). Keberkesanan Penggunaan Alat Bahan Bantu Mengajar Dalam Pelaksanaan Kursus Sains Kejuruteraan di Kalangan Pelajar Diploma Kejuruteraan di Politeknik Tuanku Sultanah Bahiyah. pp 223-230.

[33] Nan, G. \& Ziqiang, C. (2012). Explore of Teaching Practice on
Programmable Logic Conroller. Proc. of the First Int. Conference on Education Technology and Computer, vol 43.

[34] Ng, Y. S. (2004). Amalan Penggunaan Alat Bantu Mengajar (ABM) di Kalangan Guru-Guru Teknikal Sekolah Menengah Teknik, Negeri Kedah. Universiti Teknologi Malaysia: Tesis Ijazah Sarjana.

[35] Pathmantara, S., Wibawa, A. P. \& Rahayu, S. (2015). An Industrial Machine Prototype for Learning PLC at Vocational High School. Global Journal of Engineering Education, 17(3), 138-142.

[36] Nik Azis, N. A. (1999). Pendekatan Konstruktivisme Radikal Dalam Pendidikan Matematik. Kuala Lumpur: Penerbit Universiti Malaya.

[37] Prayoga, I. N. (2013). Penerapan Media Belajar Trainer PLC Omron Portabel UntukMeningkatkan Hasil Belajar Siswa Tentang Pemrogram PLC. Universitas Pendidikan Indonesia Bandung: Tesis Sarjana.

[38] Salleh, A. (2007). Keberkesanan Kaedah Pembelajaran Berbantukan Komputer (Penggunaan Perisian Power Point Interaktif) Terhadap Peningkatan Penguasaan Konsep Konsep Sains Dalam Tajuk Sel Untuk Sains Tingkatan Satu. Universiti Terbuka Malaysia: Tesis Sarjana.

[39] Suparta, D. (2014). Penerapan Trainer Kit Programmable Logic Controller Sebagai Media Pembelajaran Membuat Rangkaian Kontrol Motor. Universitas Pendidikan Indonesia Bandung: Tesisi Sarjana.

[40] Sustina, Y. (2013). Penerapan Pendekatan Konstruktivisme Untuk Meningkatkan Hasil Belajar Siswa Pada Pembelajaran IPA di Sekolah Dasar. Universitas Pendidikan Indonesia: Tesis Sarjana.

[41] Wan Harun, M. A., Ruskam, A., Baharuddin, A. S. \& Sarip, M. A. (2015). Epistemologi Praktik Bahan Bantu Mengajar Nabawi Dalam Pengajaran dan Pengajaran. International Journal of Islamic and Civilation Studies, 2(2), pp 45-55.

[42] Yang, S. C. (2001). Synergy of constructivism and Hypermedia from Three Constructivist Perspectives: Social, Semiotic and Cognitive. Educational Computing Research, 24(4), 321-362.

[43] Zakaria, S. N. (2015). Kesan Pendekatan Konstruktivisme dan Pendekatan Tradisional Dalam Pengajaran dan Pembelajaran Komponen Sstera Bahasa Melayu. Jurnal Pendidikan Bahasa Melayu- JPBM, 5(2), 12-21. 